Perafán, H. (2018). Board gender diversity and earnings quality. Evidence from the Latin American integrated market (MILA). Contaduría Universidad de Antioquia, 72, 151-163

Doi: https://doi.org/10.17533/udea.rc.n72a08

\title{
Board gender diversity and earnings quality. Evidence from the Latin American integrated market (MILA)
}

Héctor Fabio Perafán Peña

hfperafan@icesi.edu.co

Universidad Icesi 


\section{Board gender diversity and earnings quality. Evidence from the Latin American integrated market (MILA)}

Resumen: La diversidad de género de las juntas directivas es un tema que recientemente ha ganado interés en la investigación en finanzas corporativas. No obstante, hay muy pocos estudios que analizan su influencia sobre la calidad de la información financiera en los mercados desarrollados. Esta situación no es mejor para los mercados emergentes, donde, excepto por China, este tipo de estudios es casi inexistente. De esta forma, esta investigación analiza la relación entre la diversidad de género de las juntas directivas y la calidad de información financiera en Latinoamérica, enfocándose en el Mercado Integrado Latinoamericano (MILA), que lo componen las empresas cotizadas en las bolsas de valores de México, Chile, Perú y Colombia. Con un panel de datos de 361 observaciones del periodo comprendido entre los años 2002 y 2014, este trabajo realiza regresiones de mínimos cuadrados ordinarios $(M C O)$ que dan cuenta de una relación en forma de U invertida entre la diversidad de género de las juntas directivas y la calidad de la información financiera, después de controlar por otras variables tales como el tamaño, apalancamiento, ROA, flujo de caja operativo, pérdidas contables e industria. Asimismo, los resultados indican la existencia de un nivel mínimo de diversidad de género, 30,8\% de los miembros de la junta, a partir del cual entre más mujeres se sumen a la junta directiva mejor será la calidad de la información financiera de las empresas.

Palabras clave: Calidad de la información financiera, diversidad de género, juntas directivas, Latinoamérica.

Board gender diversity and earnings quality. Evidence from the Latin American integrated market (MILA)

Abstract: Board gender diversity is an issue of recent interest in corporate finance research. Nonetheless, there are too few studies about the influence of female directors on earnings quality in the developed markets. This situation is not better for emerging markets, where, except for China, studies like this are almost nonexistent. Consequently, this paper sheds light on the relationship between board gender diversity and earnings quality in Latin America, focusing on the listed firms in Mexico, Chile, Peru, and Colombia, which integrate the Latin American Integrated Market (Mercado Integrado Latino Americano or MILA in Spanish). With a data-panel of 361 observations from the period between 2002 and 2014, this work performs OLS regressions that indicate the existence of an inverted U-shaped relationship between board gender diversity and earnings manipulation, after controlling for other variables such as size, leverage, ROA, operating cash flow, accounting losses, and industry. Furthermore, results indicate the existence of a minimum level of female directors, $30.8 \%$ of board members, from which more board gender diversity leads to higher earnings quality.

Keywords: Financial information quality, gender diversity, board of directors, Latin America.

\section{La diversité de genre et la qualité des revenus au sein des conseils d'administration des entreprises. Témoignages du Marché Integré Latino-américain (MILA)}

Résumé: La diversité de genre au sein des conseils d'administration est un sujet qui a suscité de l'intérêt dans la recherche en finances des entreprises. Néanmoins, il existe peu d'études qui aient analysé son influence sur la qualité de l'information financière dans les marchés développés. C'est aussi le cas pour les marchés émergents où - la Chine exceptée- ce type d'études est presque inexistant. Ainsi, cette recherche analyse le rapport entre la diversité de genre dans les conseils d'administration et la qualité d'information financière en Amérique Latine, se concentrant sur le Marché Integré Latino-Américan (MILA), composé par les entreprises cotées dans les bourses de valeurs de Mexique, Chili, Pérou et Colombie. Avec un panneau de données de 361 observations de la période comprise entre les années 2002 et 2014, ce travail fait des régressions des moindres carrés ordinaires (MCO) qui rendent compte d'une rélation entre la forme en U inversé entre la diversité de genre des conseils d'administrations et la qualité de l'information financière, après avoir passé par des variables telles que la taille, le levier financier, la rentabilité des actifs, le flux de trésorerie disponible, les pertes comptables et l'industrie. Du même, les résultats indiquent l'existence d'un niveau minimum de femmes dans les conseils d'administration (30,8\%). À partir de ce pourcentage l'on peut déduire que, à plus des femmes dans les conseils d'administration, plus de qualité dans l'information financière des entreprises.

Mots-clés: Qualité de l'information financière, diversité de genre, conseils d'aministration, Amérique-Latine.

\section{A diversidade de gênero nas juntas diretivas e a qualidade da informação financeira. Evidências do Mercado Integrado da América Latina (MILA)}

Resumo: A diversidade de gênero das juntas diretivas é um assunto que recentemente vem adquirindo interesse na pesquisa das finanças corporativas. No entanto, existem poucos estudos que analisam sua influência sobre a qualidade da informação financeira nos mercados desenvolvidos. Esta situação não é melhor para os mercados emergentes, onde, exceto pela China, este tipo de estudos é quase inexistente. Desta maneira, esta pesquisa analisa a relação entre a diversidade de gênero das juntas diretivas e a qualidade da informação financeira na América Latina, com foco no Mercado Integrado da América Latina (MILA), que está composto por empresas cotadas na Bolsa de Valores do México, Chile, Peru e a Colômbia. Com uma base de dados de 361 observações do período compreendido entre os anos 2002 e 2014, este trabalho realiza regressões de mínimos quadrados ordinários (MCO) que dão conta de una relação com forma de $U$ invertido entre a diversidade de gênero das juntas diretivas e a qualidade da informação financeira, depois de controlar por outras variáveis como o tamanho, alavancagem, ROA, fluxo de caixa operativo, perdas contábeis e indústria. Assim também os resultados mostram a existência de um mínimo nivel de diversidade de gênero, 30,8\% dos integrantes da junta, a partir do qual entre mais mulheres integrem a junta diretiva, melhor será a qualidade da informação financeira das empresas.

Palavras chave: Qualidade da informação financeira, diversidade de gênero, juntas diretivas, América Latina. 
Cont. udea (enero-junio), pp. 151-163. (C) Universidad de Antioquia-2018.

\title{
Board gender diversity and earnings quality. Evidence from the Latin American integrated market (MILA)
}

\author{
Héctor Fabio Perafán Peña \\ Doi: https://doi.org/10.17533/udea.rc.n72a08
}

Primera versión recibida en abril de 2018- Versión final aceptada en mayo de 2018

\section{Introduction}

Cender diversity in the board of directors is an issue that recently pays

Iattention not only to corporate finance research but also to regulators in many countries. Regarding corporate finance research, some studies find a positive association between corporate board diversity and financial performance (e.g., Campbell and Minguez-Vera, 2008; Carter et al., 2003; Erhardt, Werbel, and Shrader, 2003; Farrell and Hersch, 2005). Moreover, there are other studies looking for a better understanding of the factors why the gender of directors has an effect of their performance (Hillman, Canella, and Harris, 2002), how female directors contribute to the board's dynamics (Huse and Solberg, 2006) and the role of women focusing on committee assignments as well as the director's background (Peterson and Philpot, 2007). Although, the broad research around this topic contrasts with the fact that there is no consensus on the effect of board gender diversity over financial performance (Cabrera-Fernández, Martínez-Jiménez, and Hernández-Ortiz, 2016). That situation, summed to the fact that regulators of some western European countries (Norway, Spain, and Sweden) perform constant efforts to foster female participation on boards, recommending (Spain and Sweden) and even requiring (Norway) female participation quotas in boards (Srinidhi, Gul, and Tsui, 2011); denote the relevance and momentum for studies analyzing this subject.

From another point of view, accounting research has scarce literature of board gender diversity and its effect over earnings quality. Srinidhi et al. (2011), Niskanen, Karjalainen, and Niskanen (2011) and Thiruvadi and Huang (2012) find 
Perafán, H. Board gender diversity and earnings quality...

evidence that supports the notion that female participation in audit committees restrict earnings management, while Sun, Liu, and Lan (2011) and Ye, Zhang, and Rezaee (2010) are unable to find such a restriction. At this regard, Arun, Almahrog, and Ali Aribi (2015) and Kyaw, Olugbode, and Petracci (2015) suggest that independent female directors and countries' gender equality are factors that possible moderate the effect of board gender diversity over earnings quality.

From a theoretical point of view, there are many reasons why female directors may perform better and show higher earnings quality than her male counterparts. For example, Adams and Ferreira (2009) find in a sample of US firms that female directors have better attendance records and are more likely to join monitoring committees than male directors. Hillman et al. (2002) indicate that female directors probably enhance the board decisions because they are more prone to come from non-business backgrounds, hold advanced degrees, and join multiple boards at a faster rate than her male counterparts. Similarly, Huse and Solberg (2006) highlight that boards with gender diversity have more informed deliberations and discuss tougher issues that are often considered problematic by non-women boards.

Those studies mentioned above usually include firms in developed countries, except for some works for China, leading to a gap in the accounting literature given the importance of emerging economies. This situation is even worse in the case of Latin America, in the sense that to date this branch of research is almost non-existent.

Consequently, this works attempts to test if there is a relation between board gender diversity and earnings quality in Latin American companies, specifically for those firms listed in the major exchanges of Mexico, Chile, Colombia, and Peru, which compose the Latin American Integrated Market (MILA). At this regard, by using OLS regressions, the panel dataset of 361 observations indicate that there is an inverted $U$-shape relation between female board composition and earnings quality. Here, the McNichols (2002) model of discretionary accruals is the proxy for earnings quality. Furthermore, the results suggest that female directors need a minimum level of board gender diversity to exercise a significant influence on the board to deter earnings manipulation.

\section{Data and methodology}

The sample comprises 361 observations, for 79 firms listed in the major exchanges of Mexico (Bolsa Mexicana de Valores), Chile (Bolsa de Santiago), Colombia (Bolsa de Valores de Colombia), and Peru (Bolsa de Valores de Lima). This paper uses the data available in Worldscope for the financial statements for the period from 2002 through 2014, incorporating the assets, current assets, gross property plant and equipment, cash, liabilities, current liabilities, 
short-term debt, common shareholders' equity, market capitalization, revenues, net income before extraordinary items and operating cash flow. For the corporate board characteristics, this study collects the board size and board gender diversity (as the percentage of women over the number of boards' members) from the ESG-ASSET4 database. For a detailed description of all variables included in this study please see Table 1.

Table 1. Variables description

\begin{tabular}{cl}
\hline Symbol & \\
\hline$\Delta \mathrm{CA}_{\mathrm{it}}$ & Change in current assets \\
$\Delta \mathrm{Cash}_{\mathrm{it}}$ & Change in cash \\
$\Delta \mathrm{CL}_{\mathrm{it}}$ & Change in current liabilities \\
$\Delta \mathrm{STD}_{\mathrm{it}}$ & Change in short-term debt \\
$\Delta \mathrm{WC}_{\mathrm{it}}$ & $=\left(\Delta \mathrm{CA}_{\mathrm{it}}-\Delta \mathrm{Cash}_{\mathrm{it}}\right)-\left(\Delta \mathrm{CL}_{\mathrm{it}}-\Delta \mathrm{STD}_{\mathrm{it}}\right)$ \\
$\mathrm{CFO}_{\mathrm{i}, \mathrm{t}}$ & Cash flow from operations \\
$\Delta \mathrm{Sales}_{\mathrm{i}, \mathrm{t}}$ & Change in revenues \\
$\mathrm{PPE}_{\mathrm{i}, \mathrm{t}}$ & Gross property plant and equipment \\
$A E E_{i t}$ & Absolute error estimation of Equation 1 \\
$B G D_{i, t}$ & Number of female directors over (percentage) \\
$B S_{i, t}$ & Number of board directors \\
$S I Z E_{i, t}$ & Natural logarithm of revenues \\
$L E V_{i, t}$ & The ratio between liabilities over assets \\
$\operatorname{GSALSS}$ & Percentage of change between revenues in period t and revenues in period t-1 \\
$M T B_{i, t}$ & The ratio for market capitalization over equity book value \\
$L O S S_{i, t}$ & Dummy variable that takes the value of 1 if the net income is negative and 0 otherwise \\
\hline
\end{tabular}

To estimate the discretionary accruals, this research uses an adjusted version of McNichols (2002) model for earnings management as Srinidhi et al. (2011) because it considers the cash flows synchronicity with current accruals proposed by Dechow and Dichev (2002), as well as the abnormal accruals estimation of Jones (1991) and Dechow, Sloan, and Sweeney (1995). In this sense, the model of McNichols (2002) follows the next specification:

$$
\Delta \mathrm{WC}_{\mathrm{it}}=\alpha_{0 \mathrm{i}}+\alpha_{1 \mathrm{j}} \mathrm{CFO}_{\mathrm{i}, \mathrm{t}-1}+\alpha_{2 \mathrm{j}} \mathrm{CFO}_{\mathrm{i}, \mathrm{t}}+\alpha_{3 \mathrm{j}} \mathrm{CFO}_{\mathrm{i}, \mathrm{t}+1}+\alpha_{4, \mathrm{j}} \Delta \mathrm{Sales}_{\mathrm{i}, \mathrm{t}}+\alpha_{5 \mathrm{j}} \mathrm{PPE}_{\mathrm{i}, \mathrm{t}}+\varepsilon_{\mathrm{it}}
$$

Consistent with Francis, LaFond, Olsson, and Schipper (2005) the change in working capital $\left(\Delta \mathrm{WC}_{\mathrm{it}}\right)$ is the dependent variable and the net cash flow from operations (CFO), the change in revenues $\left(\triangle\right.$ Sales $\left._{\mathrm{i}, \mathrm{t}}\right)$ and the gross property plant and equipment $\left(\mathrm{PPE}_{\mathrm{i}, \mathrm{t}}\right)$ are the independent variables. Here and after, $\mathrm{i}$ denotes firms and $\mathrm{j}$ denotes years. $\varepsilon_{\mathrm{it}}$ stands for the error term. In addition, all the 
Perafán, H. Board gender diversity and earnings quality...

variables in Equation 1 are scaled by the average total assets between year t-1 and year t. As Srinidhi et al. (2011), here the proxy for earnings quality variable is the absolute error term (AEE) estimation of Equation 1. AEE computing involves the error term estimation by cross-sectional regressions using year and industry groups. The choice of this measure is supported by the fact that AEE incorporates not only the income increasing discretionary accruals (DA's) but also the income decreasing DA's besides the reversal of previous DA's (Hutton, Marcus, and Tehranian, 2009). Hence, positive figures for AEE indicate earnings manipulation and therefore low earnings quality.

With the one can proceed to assess the effect of board gender diversity using the multivariate-model regression of Arun et al. (2015) as follows:

$$
\begin{aligned}
& A E E_{i t}=\alpha_{0 i}+\alpha_{1} B G D_{i, t}+\alpha_{2} B S_{i, t}+\alpha_{3} C_{F O_{i, t}}+\alpha_{4} S_{4} I Z E_{i, t}+\alpha_{5} R O A_{i, t}+\alpha_{6} L E V_{i, t}+\alpha_{7} G S A L E S_{i, t}+ \\
& \alpha_{8} M T B_{i, t}+\alpha_{9} L O S S_{i, t}+\varphi_{i t}
\end{aligned}
$$

Here, the dependent variable is $A E E_{i t}$, the board gender diversity $\left(B G D_{i, t}\right)$ is the interested variable and the control variables are board size $\left(B S_{i, t}\right)$, cash flow from operations $\left(C F O_{i, t}\right)$, size $\left(S I Z E_{i, t}\right)$, ROA $\left(R O A_{i, t}\right)$, leverage $\left(L E V_{i, t}\right)$, sales growth (GSALES), market to book ratio $\left(M T B_{i, t}\right)$ and accounting losses $\left(\operatorname{LOSS}_{i, t}\right)$. As Arun et al. (2015), this specification includes fixed effects for year, industry and country, since earnings management behavior can depend on the heterogeneity around these factors.

Descriptive statistics and the correlation matrix for the variables mentioned above are available in Table 2 and Table 3 respectively. Note that the dependent and independent variables are winsorized at $1 \%$ to mitigate the effect of outliers. Most of the firm-year observations in the sample are from Mexican firms (195 obs.), followed by companies from Chile (114 obs.), Peru (30 obs.) and Colombia (22 obs.). On average, the number of board members in the MILA is twelve members, and the female participation is low with $5.15 \%$ of board members. In general, firms show positive returns (6.47\%) over their investment in assets (ROA) and are highly levered (LEV) with almost half of the assets $(45.29 \%)$ funded by outsiders. Besides, investors value net assets investments higher than its accounting figures (book values), as the market to book ratio indicates (2.72).

Regarding the interest variable, after performing the cross-sectional regressions for Equation 1, the as AAE figures in Table 2 show that on average firms in the sample manipulate earnings (13.35\%). Additionally, the correlation matrix indicates that there are not multicollinearity problems between the variables of Equation 1, besides the fact that coefficients are in line prior research in the field. At this regard, MTB correlations with CFO and ROA are the highest figures with 0.496 and 0.463 respectively. 
Table 2. Descriptive statistics

\begin{tabular}{lrrrr}
\hline & \multicolumn{1}{c}{ Mean } & \multicolumn{1}{c}{ SD } & \multicolumn{1}{c}{ Min } & \multicolumn{1}{c}{ Max } \\
\hline DWC $^{*}$ & $0.84 \%$ & $6.16 \%$ & $-19.53 \%$ & $25.53 \%$ \\
CFO $^{\circ}$ & $11.24 \%$ & $6.14 \%$ & $-14.55 \%$ & $30.15 \%$ \\
DSALES $^{*}$ & $4.52 \%$ & $12.82 \%$ & $-27.89 \%$ & $51.56 \%$ \\
PPE $^{*}$ & $76.54 \%$ & $34.82 \%$ & $6.31 \%$ & $189.70 \%$ \\
AEE & $13.35 \%$ & $14.16 \%$ & $0.04 \%$ & $77.54 \%$ \\
BGD & $5.15 \%$ & $8.30 \%$ & $0.00 \%$ & $35.71 \%$ \\
BS & 12.12 & 5.26 & 4 & 33 \\
SIZE & 8.55 & 1.07 & 6.28 & 10.53 \\
CFO & $10.67 \%$ & $6.08 \%$ & $-22.44 \%$ & $30.91 \%$ \\
ROA & $6.47 \%$ & $5.53 \%$ & $-11.66 \%$ & $24.43 \%$ \\
LEV & $45.29 \%$ & $16.36 \%$ & $7.17 \%$ & $80.80 \%$ \\
GSALES & $8.21 \%$ & $20.14 \%$ & $-36.57 \%$ & $88.00 \%$ \\
MTB & 2.72 & 1.39 & 0.36 & 9.26 \\
LOSS & 0.05 & 0.21 & 0 & 1 \\
$\mathrm{~N}$ & 361 & & & \\
\hline NOte: & & & & \\
\hline
\end{tabular}

Note: * indicates that variables are deflated by the average total assets between year $\mathrm{t}-1$ and year $\mathrm{t}$.

Table 3. Correlation matrix

\begin{tabular}{|c|c|c|c|c|c|c|c|c|c|c|c|}
\hline & DWC & AEE & BGD & BS & SIZE & CFO & ROA & LEV & GSALES & MTB & LOSS \\
\hline DWC & 1 & & & & & & & & & & \\
\hline AEE & 0.135 & 1 & & & & & & & & & \\
\hline BGD & 0.0495 & -0.179 & 1 & & & & & & & & \\
\hline BS & 0.0490 & -0.0605 & $0.163^{m}$ & 1 & & & & & & & \\
\hline SIZE & -0.0377 & $-0.163^{-}$ & $0.288^{-\infty}$ & $0.451^{-m}$ & 1 & & & & & & \\
\hline CFO & 0.0987 & $0.123^{-\prime}$ & -0.0608 & $0.115^{\infty}$ & $0.121^{\prime \prime}$ & 1 & & & & & \\
\hline ROA & 0.0460 & $0.190^{-}$ & 0.0336 & 0.0635 & -0.0550 & $0.591^{-m}$ & 1 & & & & \\
\hline LEV & $-0.108^{\circ}$ & $-0.271^{--}$ & -0.0653 & -0.0720 & $0.239^{-m}$ & $-0.272^{-}$ & $-0.449=$ & 1 & & & \\
\hline GSALES & $0.119^{\prime \prime}$ & -0.125 & 0.0165 & 0.0668 & $0.116^{\mathrm{m}}$ & 0.0364 & 0.154 & 0.0428 & 1 & & \\
\hline МТВ & 0.0914 & 0.0708 & $0.149^{--}$ & $0.201^{-}$ & $0.214^{-m}$ & $0.496^{--}$ & $0.463^{-m}$ & 0.0851 & 0.0686 & 1 & \\
\hline LOSS & -0.0483 & 0.0458 & $-0.121^{* \prime}$ & $-0.147^{-\infty}$ & -0.0577 & $-0.230^{-m}$ & $-0.441^{-\cdots}$ & $0.0874^{*}$ & -0.0834 & -0.0587 & 1 \\
\hline
\end{tabular}

\section{Empirical results}

Table 4 shows regressions results for the effect of board diversity over AEE as stated in Equation 2. Here, the base model (without BGD and BS) in the first column, have a good fit in the sense that it explains the $61 \%$ of changes in AEE and have a significant F-statistic. Furthermore, most of the control variables are significant at some level, except for the leverage and ROA.1 At

1 Even though LEV and ROA are not significant, they show the same signs of Arun et al. (2015). 
Perafán, H. Board gender diversity and earnings quality...

this regard, Table 4 indicates that SIZE and CFO are negative and significant, which are in line the literature review perform by Arun et al. (2015). Although, remain variables present different signs or significance from their empirical results. This situation should not be an issue since Arun et al. (2015) specify that from a theoretical point of view there are not expected signs for those variables. Besides, one can argue that coefficients fit with prior accounting literature. For example, firms with accounting losses can experiment current income-decreasing accruals by new managers that want to exacerbate their performance in future years or the so-called big baths. 2 In addition, concerning to the CFO sign and significance, one can pose that companies manipulating earnings may want to report smooth net income figures with the aim of incorporate future opportunities that can improve the informativeness of financial information, but probably are fuzzy by the variability of current cash flows from operations (Tucker and Zarowin, 2006).

Regarding GSALES, the reasoning above perfectly suits with its coefficient and significance results because companies with promising prospects (sales growth) are more prone to manipulate earnings in order to improve earnings informativeness. Also, the BS coefficient, positive and significant, suggest that the higher the number of board members, the higher the manipulation, following Kyaw et al. (2015).

Table 4. OLS model for female participation on the board

\begin{tabular}{|c|c|c|c|c|}
\hline Dependent variable: & (1) & (2) & (3) & (4) \\
\hline AEE & $b / t$ & $b / t$ & $\mathbf{b} / \mathbf{t}$ & $b / t$ \\
\hline \multirow[t]{2}{*}{ BGD } & & 0.07906 & $0.40875^{* * * * 6}$ & $0.40875^{\text {粎米 }}$ \\
\hline & & [1.07] & [2.08] & [2.59] \\
\hline \multirow[t]{2}{*}{$\mathrm{BGD}^{\wedge} 2$} & & & $-1.32551^{*}$ & $-1.32551^{\text {橉 }}$ \\
\hline & & & {$[-1.81]$} & {$[-2.58]$} \\
\hline \multirow[t]{2}{*}{ BS } & $0.00465^{* * * *}$ & $0.00450^{\text {档 }}$ & $0.00386 \%$ & $0.00386^{\text {橉 }}$ \\
\hline & [2.29] & [2.21] & [1.88] & [2.05] \\
\hline \multirow[t]{2}{*}{ MTB } & $0.01531^{\text {米米 }}$ & 0.01394 橉 & $0.01477^{\text {粎 }}$ & $0.01477^{\text {䊉 }}$ \\
\hline & [2.73] & [2.42] & [2.57] & [2.28] \\
\hline \multirow[t]{2}{*}{ SIZE } & $-0.01290^{*}$ & -0.01585 *** & -0.01536 橉 & -0.01536 档 \\
\hline & {$[-1.86]$} & {$[-2.13]$} & [-2.07] & {$[-2.46]$} \\
\hline \multirow[t]{2}{*}{ GSALES } & $0.08447^{* * * *}$ & $0.08671^{\text {**** }}$ & $0.07969^{* * * *}$ & $0.07969^{*}$ \\
\hline & [2.13] & [2.18] & {$[2.00]$} & [1.94] \\
\hline \multirow[t]{2}{*}{ LOSS } & $0.05242^{*}$ & $0.06015^{*}$ & $0.06428^{* * * *}$ & $0.06428^{*}$ \\
\hline & [1.68] & [1.88] & [2.01] & [1.82] \\
\hline \multirow[t]{2}{*}{ CFO } & -0.25960 乘 & $-0.24129^{*}$ & $-0.24720^{*}$ & -0.24720 \\
\hline & {$[-2.02]$} & {$[-1.87]$} & [-1.92] & {$[-1.41]$} \\
\hline
\end{tabular}

2 For interested readers I suggest the work of Walsh, Craig, and Clarke (1991) for a more details on this concept. 


\begin{tabular}{|c|c|c|c|c|}
\hline Dependent variable: & (1) & (2) & (3) & (4) \\
\hline AEE & $\mathbf{b} / \mathbf{t}$ & $\mathbf{b} / \mathbf{t}$ & $\mathbf{b} / \mathbf{t}$ & $\mathbf{b} / \mathbf{t}$ \\
\hline \multirow[t]{2}{*}{ LEV } & -0.06796 & -0.05670 & -0.05410 & -0.05410 \\
\hline & {$[-1.49]$} & {$[-1.22]$} & {$[-1.16]$} & {$[-1.28]$} \\
\hline \multirow[t]{2}{*}{ ROA } & 0.04881 & 0.07378 & 0.08985 & 0.08985 \\
\hline & {$[0.29]$} & {$[0.43]$} & [0.53] & {$[0.48]$} \\
\hline \multirow[t]{2}{*}{ _cons } & 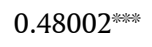 & $0.50411^{\text {米粠 }}$ & $0.50794^{* \text { 米米 }}$ & 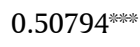 \\
\hline & [5.71] & [5.80] & [5.86] & [7.01] \\
\hline Robust standard errors & No & No & No & Yes \\
\hline Obs. & 361 & 361 & 361 & 361 \\
\hline R-sqr & 0.61 & 0.62 & 0.62 & 0.62 \\
\hline Adj-R-sqr & 0.5787 & 0.5789 & 0.5818 & 0.5818 \\
\hline F-value & 16.95 & 16.46 & 16.17 & 182.09 \\
\hline F-pvalue & 0.000 & 0.000 & 0.000 & 0.000 \\
\hline
\end{tabular}

The results of the second column of Table 4 are consistent with the signs and coefficients described above, while the goodness of fit of the model supports the inclusion of BGD. In this point, OLS estimations indicate that board gender diversity does not relate with earnings manipulation. Hence, one can posit that board gender diversity does not necessarily have a linear association with earnings manipulation and that a more refined analysis is needed to have a better notion of the type of association between those variables. Following this rationale, the coefficients of $\mathrm{BGD}$ and $\mathrm{BGD}^{\wedge} 2$ in the third column of Table 3 indicates that there is an inverted U-shaped relation between board gender diversity and earnings manipulation. Moreover, previous coefficients and significances prevail, and the adjusted r-square shows that the inclusion of $\mathrm{BGD}^{\wedge} 2$ improves the explanation power of the model. Furthermore, column four tests these results by estimating the model specification of the third column using robust standard errors. By doing so, the significance of $\mathrm{BGD}$ and $\mathrm{BGD}^{\wedge} 2$ improve, which supports the inverted $\mathrm{U}$-shaped relation of $\mathrm{AEE}$ and $\mathrm{BGD}{ }^{3}$

From the above results, it is possible to indicate that on average the minimum of female participation that deters earnings management (measured through discretionary accruals) of financial statements for companies listed in the MILA is $30.8 \%$. At this respect, despite that the inflection point of the curve between AEE and BDG is a local maximum, one can interpret it as the minimum female director participation that women need to exercise a significant influence over the board decisions related with the earnings quality.

3 It is relevant to note that signs and significance of almost all the control variables remain unchanged (only CFO is not statistically significant under this approach). 
Perafán, H. Board gender diversity and earnings quality...

\section{CONCLUSIONS}

This study fills the gap in the accounting literature around the board gender diversity on earnings quality in the Latin American context. With 361 observations of listed companies in the MILA, this research performs OLS regressions to test the relation between an earnings quality measure, AEE from McNichols (2002), and the percentage of female directors' participation on the total board members. After controlling for other factors that impact earnings manipulation, results indicate that there is a minimum level of female participation on boards (30.8\%) from which more female members enhance earnings quality. In this sense, board gender diversity and earnings manipulation are correlated in an inverted $\mathrm{U}$-shaped form.

These findings are relevant to discuss the convenience of the many efforts to empower the female director participation on boards performed by countries such as Norway, Sweden, and Spain and, why not, for future deliberations by Latin American regulatory bodies. In this sense, results indicate not all levels of board gender diversity necessarily help to enhance earnings quality. Therefore, regulators can focus on guarantying a minimum desired level of women in boards from which female board participation effectively deters earnings management.

Since this is exploratory research, there are some limitations that research can explore in the future. The first is the scarce availability of data for corporate board characteristics in Latin America. At this regard, the incorporation of available information in ESG-ASSET4 about board experience, independence, and CEO duality reduces the sample dramatically4. Future research can consider using other databases, like those involving non-public companies. The second, is the positive sign of board size (BS) in the regression results, denoting a detrimental effect of the number of board members over earnings quality, which may imply that a deeper analysis is needed in order to disentangle the role of board members on the preparation of financial information in Latin America, even if prior studies validate this type of relation.

\section{REFERENCES}

Adams, R. B., and Ferreira, D. (2009). Women in the boardroom and their impact on governance and performance. Journal of Financial Economics, 94(2), 291-309. http:// doi.org/10.1016/j.jfineco.2008.10.007

Arun, T. G., Almahrog, Y. E., and Ali Aribi, Z. (2015). Female directors and earnings management: Evidence from UK companies. International Review of Financial Analysis, 39, 137-146. http://doi.org/10.1016/j.irfa.2015.03.002

4 Moreover, Arun et al. (2015) include other variables of board characteristics like independent female directors and female chief financial officer (CFO) dummies, that are omitted in this work because of the lack of that information. 
Ascioglu, A., Hegde, S., Krishnan, G., and McDermott, J. (2012). Earnings management and market liquidity. Review of Quantitative Finance and Accounting, 38, 257-274. http:// doi.org/10.1007/s11156-010-0225-9

Cabrera-Fernández, A. I., Martínez-Jiménez, R., and Hernández-Ortiz, M.J. (2016). Women’s participation on boards of directors : a review of the literature. International Journal of Gender and Entrepreneurship, 8(1), 69-89. http://doi.org/10.1108/JJGE-02-20150008

Campbell, K., and Minguez-Vera, A. (2008). Gender diversity in the boardroom and firm financial performance. Journal of Business Ethics, 83(3), 435-451. http://doi. org/10.1007/s10551-007-9630-y

Carter, D. A., Simkins, B. J., Simpson, W. G., Borokhovich, K., Crutchley, C., Elson, C., ... Longhofer, S. (2003). Corporate Governance, Board Diversity, and Firm Value. The Financial Review, 38, 33-53. http://doi.org/10.1111/1540-6288.00034

Dechow, P. M., and Dichev, I. D. (2002). The quality of accruals and earnings: The role of accrual estimation errors. In Accounting Review (Vol. 77, pp. 35-59). http://doi. org/10.2308/accr.2002.77.s-1.61

Dechow, P. M., Sloan, R. G., and Sweeney, A. P. (1995). Detecting Earnings Management. The Accounting Review, 70(2), 193-225.

Defond, M. L., and Jiambalvo, J. (1994). Debt covenant violation and manipulation of accruals. Journal of Accounting and Economics, 17(1-2), 145-176. http://doi. org/10.1016/0165-4101(94)90008-6

Erhardt, N. L., Werbel, J. D., and Shrader, C. B. (2003). Board of director diversity and firm financial performance. Corporate Governance: An International Review, 11(2), 102-111. http://doi.org/10.1111/1467-8683.00011

Fama, E. F., and French, K. R. (1997). Industry costs of equity. Journal of Financial Economics, 43(2), 153-193. http://doi.org/10.1016/S0304-405X(96)00896-3

Farrell, K. A., and Hersch, P. L. (2005). Additions to corporate boards: The effect of gender. Journal of Corporate Finance, 11(1-2), 85-106. http://doi.org/10.1016/j. jcorpfin.2003.12.001

Francis, J., LaFond, R., Olsson, P., and Schipper, K. (2005). The market pricing of accruals quality.Journal of Accounting and Economics, 39(2), 295-327. http://doi.org/10.1016/j. jacceco.2004.06.003

Franz, D. R., HassabElnaby, H. R., and Lobo, G. J. (2014). Impact of proximity to debt covenant violation on earnings management. Review of Accounting Studies, 19(1), 473-505. http://doi.org/10.1007/s11142-013-9252-9

Ge, W., and Kim, J. B. (2014). Real earnings management and the cost of new corporate bonds. Journal of Business Research, 67(4), 641-647. http://doi.org/10.1016/j. jbusres.2013.01.021

Hales, J., and Williamson, M. G. (2010). Implicit employment contracts: The limits of management reputation for promoting firm productivity. Journal of Accounting Research, 48(1), 51-80. http://doi.org/10.1111/j.1475-679X.2009.00359.x 
Perafán, H. Board gender diversity and earnings quality...

Hillman, A. J., Canella, A. A., and Harris, I. C. (2002). Women and racial minorities in the boardroom: How do directors differ? Journal of Management. http://doi.org/10.1016/ S0149-2063(02)00192-7

Huse, M., and Solberg, A. G. (2006). Gender-related boardroom dynamics: How Scandinavian women make and can make contributions on corporate boards. Women In Management Review, 21(2), 113-130. http://doi.org/10.1108/09649420610650693

Hutton, A. P., Marcus, A. J., and Tehranian, H. (2009). Opaque financial reports, R2, and crash risk. Journal of Financial Economics, 94(1), 67-86. http://doi.org/10.1016/j. jfineco.2008.10.003

Jha, A. (2013). Earnings Management Around Debt-Covenant Violations - An Empirical Investigation Using a Large Sample of Quarterly Data. Journal of Accounting, Auditing and Finance, 28(4), 369-396. http://doi.org/10.1177/0148558X13505597

Jones, J. J. (1991). Earnings Management During Import Relief Investigations. Journal of Accounting Research, 29(2), 193-228. http://doi.org/10.2307/2491047

Kim, B. H., Lei, L., and Pevzner, M. (2010). Debt Covenant Slack and Real Earnings Management. SSRN Working Paper Series. Retrieved from http://search.proquest. com/docview/815316704? accountid $=26357$

Konan, C., Chan, L. K. C., Jegadeesh, N., and Lakonishok, J. (2006). Earnings Quality and Stock Returns. Journal of Business, 79(3), 1041-1082. Retrieved from http://www.lib. lsu.edu/apps/onoffcampus.php?url=http://search.ebscohost.com/login.aspx?direct= trueandd $\mathrm{b}=$ bthandAN $=21080240$ andsite $=$ ehost-liveandscope $=$ site

Kyaw, K., Olugbode, M., and Petracci, B. (2015). Does gender diverse board mean less earnings management? Finance Research Letters, 14, 135-141. http://doi. org/10.1016/j.frl.2015.05.006

McNichols, M. F. (2002). DISCUSSION OF The Qualityof Accruals and Earnings : The Role of Accruals Estimation Errors. The Accounting Review, 77, 61-69. http://doi.org/10.2308/ accr.2002.77.s-1.61

Niskanen, J., Karjalainen, J., and Niskanen, M. (2011). Auditor gender and corporate earnings management behavior in private Finnish firms. Managerial Auditing Journal, 26(9), 778-793. http://doi.org/10.1108/02686901111171448

Peni, E., and Vähämaa, S. (2010). Female executives and earnings management. Managerial Finance, 36(7), 629-645. http://doi.org/10.1108/03074351011050343

Peterson, C. A., and Philpot, J. (2007). Women's roles on U.S. Fortune 500 boards: Director expertise and committee memberships. Journal of Business Ethics, 72(2), 177-196. http://doi.org/10.1007/s10551-006-9164-8

Srinidhi, B., Gul, F. A., and Tsui, J. (2011). Female Directors and Earnings Quality. Contemporary Accounting Research, 28(5), 1610-1644. http://doi.org/10.1111/j.19113846.2011.01071.x

Stanley, B. W., and Sharma, V. I. (2011). To Cheat or Not to Cheat: How Bank Debt Influences the Decision to Misreport. Journal of Accounting, Auditing and Finance, 26, 383-414. http://doi.org/10.1177/0148558X11401221 
Sun, J., Liu, G., and Lan, G. (2011). Does Female Directorship on Independent Audit Committees Constrain Earnings Management? Journal of Business Ethics, 99(3), 369382. http://doi.org/10.1007/s10551-010-0657-0

Thiruvadi, S., and Huang, H.-W. (2012). Audit committee gender differences and earnings management. Gender in Management: An International Journal, 26(7), 483-498. http://doi.org/10.1108/17542411111175469

Tucker, J. W., and Zarowin, P. a. (2006). Earnings Informativeness ?, 81(1), 251-270.

Valipour, H., and Moradbeygi, M. (2010). Corporate Debt Financing and Earnings Quality. Journal of Business Finance and Accounting, 37(5-6), 538-559. http://doi.org/10.1111/ j.1468-5957.2010.02194.x

Walsh, P., Craig, R., and Clarke, F. (1991). "Big bath accounting" using extraordinary items adjustments: Australian empirical evidence. Journal of Business Finance and Accounting, 18(2), 173-189. http://doi.org/10.1111/j.1468-5957.1991.tb00587.x

Ye, K., Zhang, R., and Rezaee, Z. (2010). Does top executive gender diversity affect earnings quality? A large sample analysis of Chinese listed firms. Advances in Accounting, 26(1), 47-54. http://doi.org/10.1016/j.adiac.2010.02.008 